\title{
Justification of the Number and Type of Tire Size for a Dump Truck with a Lifting Capacity from 90 to 130 Tons
}

\author{
Dmitry Dubinkin ${ }^{1}$, Alexander Kulpin ${ }^{1}$, and Dmitry Stenin ${ }^{1}$ \\ ${ }^{1}$ T.F. Gorbachev Kuzbass State Technical University, 28, Vesennyaya street, Kemerovo, 650000, \\ Russian Federation
}

\begin{abstract}
The article substantiates the quantity and type of tire size for a dump truck with a carrying capacity from 90 to 130 tons. Types of tire sizes for dump trucks are given, as well as an analysis of applicable tires for dump trucks. An example of tire configuration for a dump truck is described, as well as the differences between projects and dump trucks with the traditional arrangement of large tires. The working productivity of large tires was calculated using the TKH "tons per kilometer per hour" technique. The general tasks that need to be addressed when designing a dump truck are highlighted. The conclusion is made on the relevance of the development of scientifically based approaches when designing dump trucks. The above data indicate that when surface mining, it is possible to solve the economic problem of reducing the operating costs of transporting minerals by applying the proposed arrangement and number of large tires when designing new dump trucks, including robotic and unmanned ones.
\end{abstract}

\section{Introduction}

Mining is a complex technological process for extracting solid, liquid and gaseous minerals from the bowels of the Earth using technical means, requiring high costs [1-15]. At present, at mining enterprises, the main types of transportation of minerals are railway, road and conveyor transport (Fig. 1). Road transport is widely used in comparison with other types of minerals transportation. The advantages of this transportation type are high maneuverability, overcoming large biases, mobility. For mining enterprises, in the extraction of subsoils, reducing operating costs for the transportation of minerals is one of the urgent economic problems.

\footnotetext{
* Corresponding author: $\underline{\mathrm{ddm} . \mathrm{tm} @ \text { kuzstu.ru }}$
} 


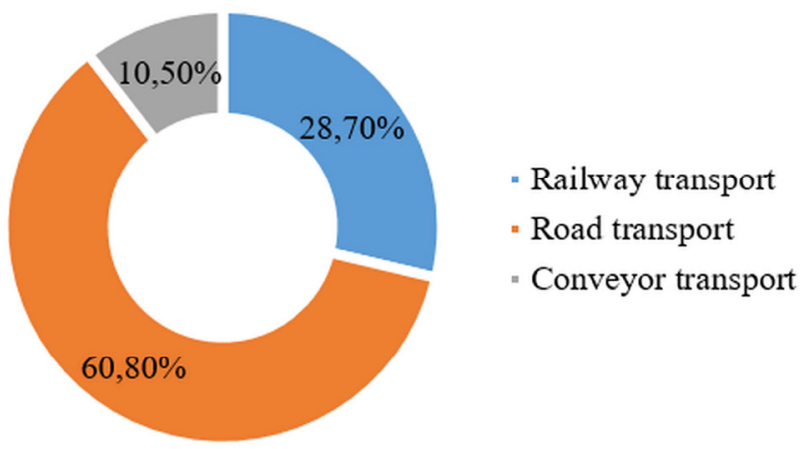

Fig. 1. Shares of transportation of minerals by various means of transport.

Large-sized special equipment includes: mining equipment, gold mining equipment, various types of loaders, industrial machinery, soil-developing machinery, various types of cranes, quarry and other types of machines.

Large-sized equipment is usually used in various difficult industrial conditions [3-10, 14]. That is why it needs special materials and spare parts. This also applies to tires for special equipment, which should have a number of features:

- high carrying capacity;

- large sizes, in comparison with passenger tires;

- high strength compared to conventional tires;

- stability and maneuverability;

- high degree of patency on roads with various surfaces (asphalt, concrete, dirt, snow, etc.);

- excellent braking and grip;

- the ability to withstand sufficiently large loads at low speeds, etc.

Operating costs include fuel, lubricants, maintenance and repair materials, tire replacement and repair, wages for drivers and repair personnel, and other expenses.

In Russia, giant tires (GTs) are used in mineral extracting and stripping transport operations of mining and processing enterprises at surface mining of iron and manganese ores. They are also used in coal surface mining (Yakutia, Kuzbass, Angren), mineral fertilizers (Kola Peninsula), etc.

The article discusses technical solutions for substantiating the number of GTs and the type of size for a quarry dump truck (QDT) with a lifting capacity of 90 to 130 tons, which solve the problem of reducing the operating costs of transporting the rock mass when developing mineral deposit by surface method[1,2] .

\section{Results and Discussion}

The main work of the GTs with increased operational characteristics is the transportation of heavy cargoes at high speeds and to a longer distance [11-15]. When choosing a GTs, it is necessary to determine the amount of work that will maintain the state of the GTs within a safe range.

The choice of GTs for a specific vehicle model and for specific operating conditions (Fig. 2 ) is determined by three main factors:

- technical specification of the vehicle, which determines the possibility of selecting the size of the GTs for a specific model of the vehicle, depending on the requirements of manufacturers of equipment and GTs;

- choice of the optimal tire tread pattern based on the nature of soil and the condition of road surface (physical and chemical properties of the soil, geometry of the road surface and the 
quality of its cleaning, fractional composition, hardness and morphology of crushed rock backfill, friability, moisture and watering of the road surface, etc.);

- load and speed characteristics of the tire (working distances, speeds, load on the tire), which determine the compliance of the tire with the actual operating loads and speeds, which affects the recommended tire pressure, as well as the choice of tread pattern and rubber composition.

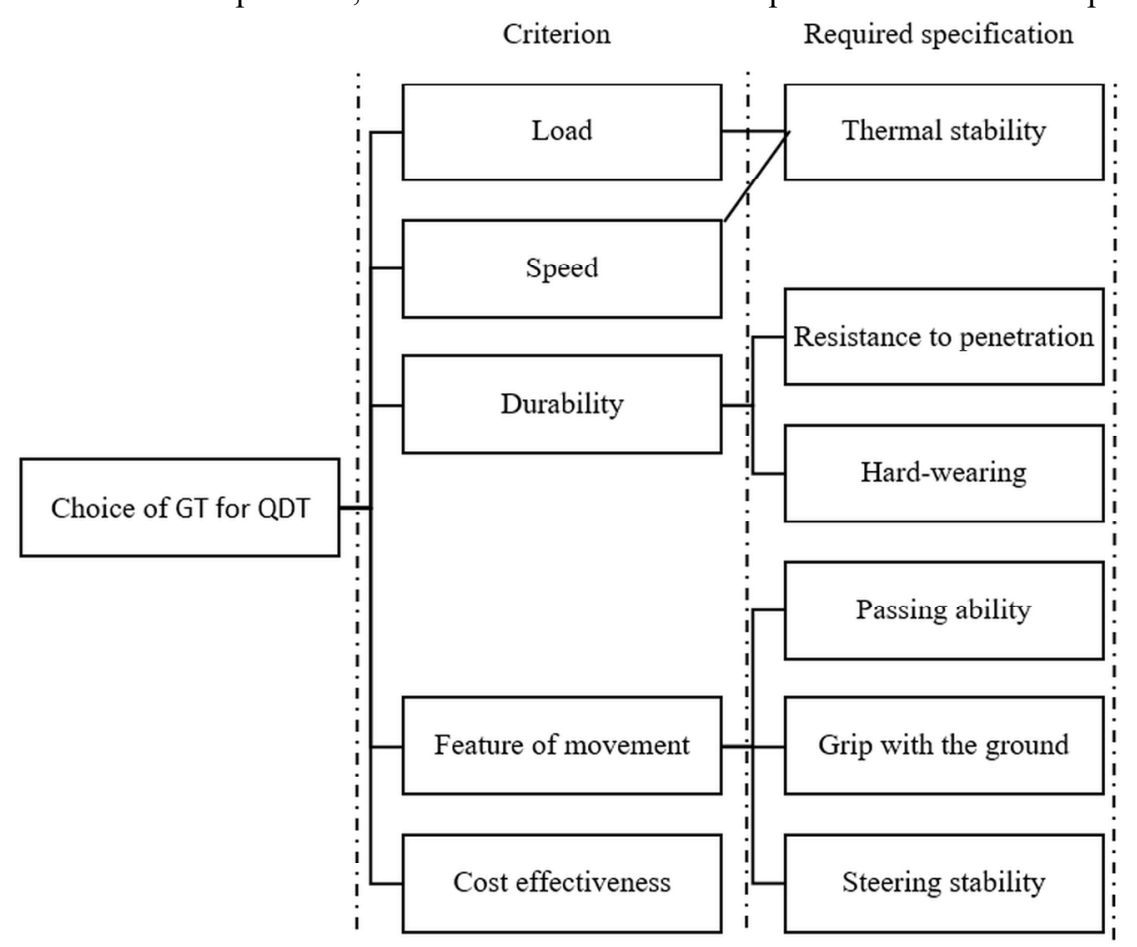

Fig. 2. The choice of GT for QDT.

The location of GTs for serial QDTs is as follows (Fig. 3): front axle -2 pcs; rear axle -4 pcs [14]. The mass distribution without load and with load on the front and rear axle at the BelAZ CS (Belarus) is shown in Fig. 4. This mass distribution of $\pm 2 \%$ without cargo and with cargo is observed in most QDTs with a lifting capacity from 90 to 130 tons of different manufacturers: Komatsu (Japan), Hitachi (Japan), LiuGong (China), XCMG (China), SANY (China ), Sinoway (China), Beml (India), BelAZ (Belarus), Liebherr (Germany), VOLVO (Sweden), Terex (Great Britain), Perlini (Italy), Caterpillar (USA), etc. 

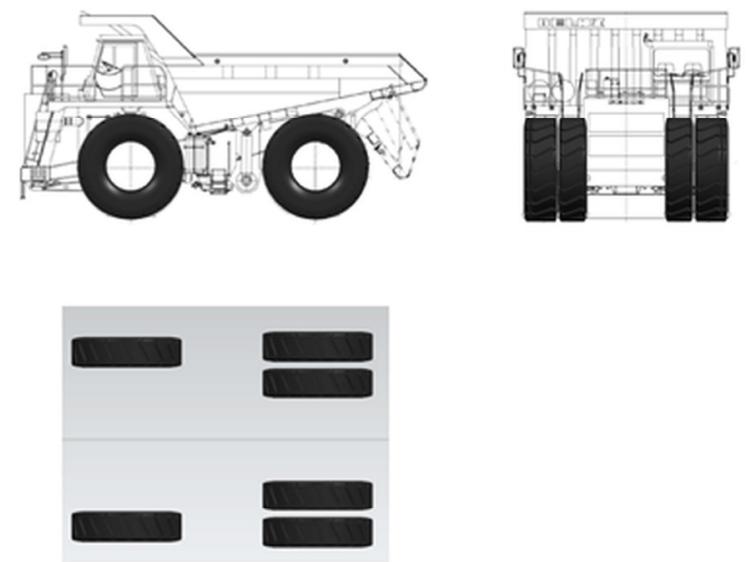

Fig. 3. The layout of the GTs for serial QDTs.
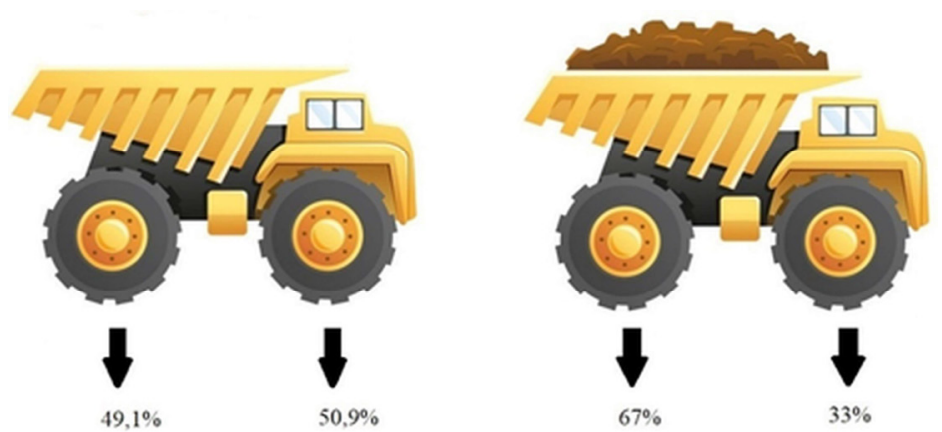

Fig. 4. The load distribution on the tires on a straight section of the road.

Radial GTs [1, 4, 14] have found wider application for strong framed dump trucks, because radial types have much more advantages than diagonal GTs, as well as recently, most tire manufacturers have refused to produce diagonal tires. Radial GTs possess high operational characteristics: wear resistance, smooth running, and long service life. The tread pattern provides reliable adhesion to the surface and self-cleaning of the tire.

Radial GTs are designed for a long service life, allow repair and are adapted to various types of mining transport units, which can be divided into working machines for loading (loaders, wheeled bulldozers, graders, etc.) and for rock mass moving. The main producers of GTs: Belshina (Belarus); Bridgestone (Japan); Michelin (France); GoodYear (USA) and others.

GTs on QDT differ in the size depending on loading capacity of the truck. The capacity range of QDT starts from 30 tons to 450 tons. Tab. 1 shows the dimensions of GTs at QDT depending on the load capacity from 90 to 180 tons.

Table 1. GTs dimensions on QDT depending on loading capacity.

\begin{tabular}{|c|c|c|c|c|c|}
\hline QDT Model & GT Size & $\begin{array}{c}\text { Carrying } \\
\text { capacity }\end{array}$ & $\begin{array}{c}\text { Average Price } \\
\text { of Belshina } \\
\text { and Chinese } \\
\text { tires * }\end{array}$ & $\begin{array}{c}\text { Average } \\
\text { Price of } \\
\text { Imported } \\
\text { Tires* }\end{array}$ & $\begin{array}{c}\approx \text { Tire } \\
\text { Weight, } \\
\text { kg** }\end{array}$ \\
\hline $\begin{array}{c}\text { BelAZ 7557, 7558; } \\
\text { Hitachi EH 1600; } \\
\text { Komatsu HD 785-7; } \\
\text { XCMG XDM91; }\end{array}$ & $\begin{array}{c}27.00 \\
\text { R49 }\end{array}$ & $90-110$ tons & 450000 RUB & $\begin{array}{c}\text { EURO } \\
9000\end{array}$ & 1300 \\
\hline
\end{tabular}




\begin{tabular}{|c|c|c|c|c|c|}
\hline $\begin{array}{c}\text { Terex TR-100; } \\
\text { VOLVO R100E; } \\
\text { Perlini DP905WD }\end{array}$ & & & & & \\
\hline $\begin{array}{c}\text { BelAZ 7513; } \\
\text { Hitachi EH 2000; } \\
\text { Komatsu HD1500-5; } \\
\text { Terex MT3300; } \\
\text { Beml BH100 }\end{array}$ & $\begin{array}{c}33.00 \\
\text { R51 }\end{array}$ & $\begin{array}{c}110-130 \\
\text { tons }\end{array}$ & 700000 RUB & $\begin{array}{l}\text { EURO } \\
16250\end{array}$ & 2300 \\
\hline $\begin{array}{c}\text { BelAZ 7517; } \\
\text { Hitachi EH 3000; } \\
\text { Komatsu HD 630E; } \\
\text { Terex MT3600B } \\
\end{array}$ & $\begin{array}{c}36.00 \\
\text { R51 }\end{array}$ & 160 tons & $\begin{array}{c}1200000 \\
\text { RUB }\end{array}$ & $\begin{array}{l}\text { EURO } \\
17400\end{array}$ & 2700 \\
\hline $\begin{array}{c}\text { BelAZ 7518; } \\
\text { Hitachi EH 3500; } \\
\text { Komatsu 730E; } \\
\text { Terex MT3700B; } \\
\text { Liebherr T252 } \\
\end{array}$ & $\begin{array}{c}37.00 \\
\text { R57 }\end{array}$ & 180 tons & - & $\begin{array}{l}\text { EURO } \\
23200\end{array}$ & 3200 \\
\hline
\end{tabular}

* Table 1 shows approximate prices for $1 \mathrm{GT}$ and corresponds to brands such as Belshina and Chinese tires, as well as imported tires such as Michelin (France), Bridgestone (Japan) and GoodYear (USA), which costs about the same, but much more expensive than Belshina and Chinese tires. duction.

** The mass of GT depends not only on the manufacturer, but also depends on the technology of pro-

Due to exposure to heavy traffic conditions, a tire with temperature limitations inevitably heats up. If this limitation is reached, tire wearing begins at an early stage of operation. Therefore, when choosing tires, it is necessary to determine the amount of work that the tire can withstand without overheating when operating the vehicle under specified conditions.

As the main technical characteristic of the operational capabilities of GTs, an indicator is used - the operational productivity of the high-frequency current (ton per kilometers per hour) or high-frequency heat-exchange (ton per miles per hour). Formula (1) is used to convert $T K H$ to $T M H$ :

$$
T K H=0.685 \times T M H
$$

$T K H$ is a function of the nominal load for a given tire size, the number of kilometers (miles) per hour, permissible for this type of tire and is calculated by the following formula (2):

where: $Q_{a v}$ - average tire load, tons;

$$
T K H=Q_{a v} \times V_{a v}
$$

$V_{\mathbf{a v}}$ - average operating speed per working day, $\mathrm{km} / \mathrm{h}$ :

$$
Q_{a v}=\frac{Q_{e}+Q_{l}}{2}
$$

where: $Q_{e}-$ empty dump truck's tire load, tons;

$Q_{l}$ - loaded dump truck's tire load, tons.

$$
V_{a v}=\frac{2 L \times N_{v}}{T}
$$

where: $L$ - leverage (the length of the trip with the cargo in one direction), km;

$N_{v}$ - number of haul cycle (maximum number of cycles per shift);

$T$ - total number of working hours of the compressor station (shift time), hours.

Thus, using TKH we can calculate the operational performance of the tires and thereby distribute the load attributable to each tire individually. Tab. 2-5 discuss the technical characteristics of GTs from different manufacturers. 
Table 2. Technical characteristics of GTs from the manufacturer Michelin (France).

\begin{tabular}{|c|c|c|c|c|c|}
\hline \multirow[b]{2}{*}{ GT Size } & \multicolumn{5}{|c|}{ Michelin } \\
\hline & $\begin{array}{l}\text { Maximum } \\
\text { Distance per } \\
\text { hour** }\end{array}$ & TKH & $\begin{array}{l}\text { Load } \\
\text { Index }\end{array}$ & $\begin{array}{c}\text { Maximum } \\
\text { Tire Load, kg }\end{array}$ & $\begin{array}{c}\text { Maximum } \\
\text { Speed, km / } \\
\text { h }\end{array}$ \\
\hline $27.00 \mathrm{R} 49$ & from 18 to 50 & $\begin{array}{c}\text { from } 392 \text { to } \\
1090\end{array}$ & 225 & 29850 & $\begin{array}{c}\text { from } 20 \text { to } \\
50\end{array}$ \\
\hline 33.00 R51 & from 16 to 45 & $\begin{array}{c}\text { from } 496 \text { to } \\
1395\end{array}$ & 232 & 35800 & $\begin{array}{l}\text { from } 20 \text { to } \\
50\end{array}$ \\
\hline 36.00 R51 & from 20 to 40 & $\begin{array}{c}\text { from } 740 \text { to } \\
1480\end{array}$ & 244 & 51000 & $\begin{array}{c}\text { from } 50 \text { to } \\
60\end{array}$ \\
\hline 37.00 R57 & from 20 to 30 & $\begin{array}{c}\text { from } 848 \text { to } \\
1272\end{array}$ & 249 & 58450 & $\begin{array}{l}\text { from } 50 \text { to } \\
60\end{array}$ \\
\hline
\end{tabular}

Table 3. Technical characteristics of GTs from the manufacturer Bridgestone (Japan).

\begin{tabular}{|c|c|c|c|c|c|}
\hline \multirow{2}{*}{ GT Size } & \multicolumn{5}{|c|}{ Bridgestone } \\
\cline { 2 - 6 } & $\begin{array}{c}\text { Maximum } \\
\text { Distance per } \\
\text { hour** }\end{array}$ & TKH & $\begin{array}{c}\text { Load } \\
\text { Index }\end{array}$ & $\begin{array}{c}\text { Maximum } \\
\text { Tire Load, kg }\end{array}$ & $\begin{array}{c}\text { Maximum } \\
\text { Speed, km / } \\
\text { h }\end{array}$ \\
\hline 27.00 R49 & - & from 415 to 486 & 223 & 27500 & 50 \\
\hline 33.00 R51 & - & 591 & 235 & 38750 & 50 \\
\hline 36.00 R51* & - & - & - & - & - \\
\hline 37.00 R57 & - & 694 & 245 & 51500 & 50 \\
\hline
\end{tabular}

Table 4. Technical characteristics of GTs from the manufacturer GoodYear (USA).

\begin{tabular}{|c|c|c|c|c|c|}
\hline \multirow[b]{2}{*}{ GT Size } & \multicolumn{5}{|c|}{ GoodYear } \\
\hline & $\begin{array}{c}\text { Maximum } \\
\text { Distance per } \\
\text { hour** }\end{array}$ & TKH & $\begin{array}{l}\text { Load } \\
\text { Index }\end{array}$ & $\begin{array}{c}\text { Maximum } \\
\text { Tire Load, kg }\end{array}$ & $\begin{array}{c}\text { Maximum } \\
\text { Speed, km / } \\
\mathbf{h}\end{array}$ \\
\hline $27.00 \mathrm{R} 49$ & - & from 394 to 500 & 223 & 27500 & 50 \\
\hline $33.00 \mathrm{R} 51$ & - & 785 & 235 & 38750 & 50 \\
\hline $36.00 \mathrm{R} 51$ & - & 825 & 241 & 46250 & 50 \\
\hline $37.00 \mathrm{R} 57$ & - & 694 & 245 & 51500 & 50 \\
\hline
\end{tabular}

Table 5. Technical characteristics of GTs from the manufacturer Belshina (Belarus).

\begin{tabular}{|c|c|c|c|c|c|}
\hline \multirow{2}{*}{ GT Size } & \multicolumn{5}{|c|}{ Belshina } \\
\cline { 2 - 6 } & $\begin{array}{c}\text { Maximum } \\
\text { Distance per } \\
\text { hour** }\end{array}$ & TKH & $\begin{array}{c}\text { Load } \\
\text { Index }\end{array}$ & $\begin{array}{c}\text { Maximum } \\
\text { Tire Load, kg }\end{array}$ & $\begin{array}{c}\text { Maximum } \\
\text { Speed, km / } \\
\text { h }\end{array}$ \\
\hline 27.00 R49 & - & from 415 to 510 & 223 & 27250 & 50 \\
\hline 33.00 R51 & - & from 430 to 630 & 236 & 40100 & 50 \\
\hline 36.00 R51 & - & from 450 to 643 & 241 & 46250 & 50 \\
\hline 37.00 R57* & - & - & - & - & - \\
\hline
\end{tabular}

* There are no data on the size of GT.

** The indicator of technical characteristics is not in the manufacturer catalogs.

Comparative analysis of the existing GTs configuration schemes for serial QDT presented in Fig. 3, and proposed GTs location is shown in Fig. 5. The calculation results are shown in Tab. 6-7. For the calculations, the main performance indicators of the technological transport were analyzed for coal mines of Kuzbass, which showed that the average operating speed of the QDT per working day $\left(V_{a v}, \mathrm{~km} / \mathrm{h}\right)$ is from 12 to $30 \mathrm{~km} / \mathrm{h}$, and the average kilometrage of the QDT per day is $240-320 \mathrm{~km}$. The mass distribution without load and with load on the front and rear axles of serial QDT are adopted as shown in Fig. 4. 

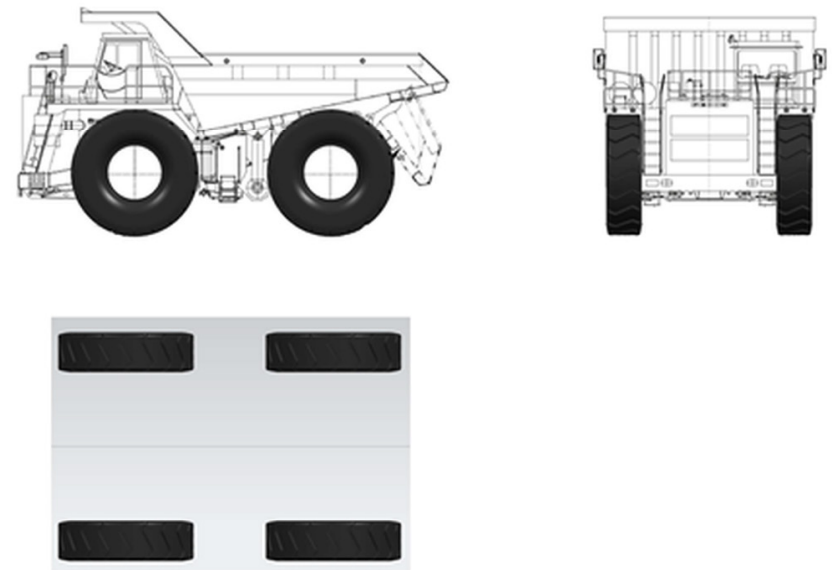

Fig. 5. The proposed layout of the GTs at serial QDT.

Table 6. Comparative calculation of serial configuration of GTs (number of tires -6 pcs.).

\begin{tabular}{|c|c|c|c|c|c|c|}
\hline QDT Model & $\begin{array}{c}\text { BelAZ- } \\
7557 \\
\end{array}$ & $\begin{array}{l}\text { Komatsu } \\
\text { HD 785-7 } \\
\end{array}$ & $\begin{array}{c}\text { BelAZ- } \\
75131 \\
\end{array}$ & $\begin{array}{c}\text { Komatsu } \\
\text { HD 1500-7 }\end{array}$ & $\begin{array}{c}\text { BelAZ- } \\
7517 \\
\end{array}$ & $\begin{array}{l}\text { Komatsu } \\
\text { HD 630E } \\
\end{array}$ \\
\hline GT Size & $27.00 \mathrm{R} 49$ & $27.00 \mathrm{R} 49$ & 33.00R51 & 33.00R51 & 36.00 R51 & 36.00 R51 \\
\hline $\begin{array}{l}\text { Maximum } \\
\text { Tire Load } \\
\text { (Michelin), t }\end{array}$ & 29.85 & 29.85 & 35.80 & 35.80 & 51.00 & 51.00 \\
\hline $\mathrm{TKH}_{\mathrm{CP}}{ }^{*}$ & 682.10 & 645.00 & 1010.53 & 1026.05 & 1239.20 & 1205.97 \\
\hline $\mathrm{TKH}_{\mathrm{CP} 2} *$ & 543.95 & 558.75 & 807.99 & 821.81 & 935.87 & 940.90 \\
\hline $\mathrm{Q}_{\mathrm{av} 1, \mathrm{~T}}$ & 22.74 & 21.50 & 33.68 & 34.20 & 41.31 & 40.20 \\
\hline $\mathrm{Q}_{\mathrm{av} 2, \mathrm{~T}}$ & 18.13 & 18.63 & 26.93 & 27.39 & 31.20 & 31.36 \\
\hline $\mathrm{V}_{\mathrm{av}}, \mathrm{km} / \mathrm{h}$ & 30 & 30 & 30 & 30 & 30 & 30 \\
\hline $\begin{array}{c}\text { Maximum } \\
\text { Load, } \mathrm{t}\end{array}$ & 90.00 & 91.00 & 136.00 & 141.00 & 160.00 & 172.00 \\
\hline $\begin{array}{c}\text { Empty Dump } \\
\text { Truck Weight, } \\
\mathrm{t}\end{array}$ & 73.00 & 72.00 & 107.10 & 107.60 & 134.00 & 124.00 \\
\hline $\begin{array}{c}\text { Front Axis } \\
\text { Tire Load } \\
\text { (Empty), t }\end{array}$ & 18.579 & 16.920 & 27.257 & 27.384 & 34.103 & 31.558 \\
\hline $\begin{array}{c}\text { Rear Axis Tire } \\
\text { Load (Empty), } \\
t\end{array}$ & 8.961 & 9.540 & 13.147 & 13.147 & 13.147 & 13.147 \\
\hline $\begin{array}{c}\text { Front Axis } \\
\text { Tire Load } \\
\text { (Loaded), t }\end{array}$ & 26.895 & 26.080 & 40.112 & 41.019 & 48.510 & 48.840 \\
\hline $\begin{array}{l}\text { Rear Axis Tire } \\
\text { Load } \\
\text { (Loaded), } \mathrm{t}\end{array}$ & 27.303 & 27.710 & 40.719 & 41.641 & 49.245 & 49.580 \\
\hline
\end{tabular}

* CP1 is the front axle, CP2 is the rear axle. 
Table 7. Comparative calculation of the proposed GTs configuration scheme (number of tires -4 pcs.; load distribution along the axles with and without cargo: $\mathrm{CP} 1=50 \%, \mathrm{CP} 2=50 \%$ ).

\begin{tabular}{|c|c|c|c|}
\hline QDT Model & QDT Project 1 & QDT Project 2 & QDT Project 3 \\
\hline GT Size & $33.00 \mathrm{R} 51$ & $36.00 \mathrm{R} 51$ & $37.00 \mathrm{R} 57$ \\
\hline $\begin{array}{l}\text { Maximum Tire Load } \\
\text { (Michelin), } \mathrm{t}\end{array}$ & 35.80 & 51.00 & 58.40 \\
\hline $\mathrm{TKH}_{\mathrm{CP} 1} *$ & 862.50 & 1087.50 & 1312.50 \\
\hline $\mathrm{TKH}_{\mathrm{CP} 2} *$ & 862.50 & 1087.50 & 1312.50 \\
\hline $\mathrm{Q}_{\mathrm{av} 1, \mathrm{~T}}$ & 28.75 & 36.25 & 43.75 \\
\hline $\mathrm{Q}_{\mathrm{av} 2, \mathrm{~T}}$ & 28.75 & 36.25 & 43.75 \\
\hline $\mathrm{V}_{\mathrm{av}}, \mathrm{km} / \mathrm{h}$ & 30 & 30 & 30 \\
\hline Maximum Load, $\mathrm{t}$ & 90.00 & 110.00 & 130.00 \\
\hline $\begin{array}{c}\text { Empty Dump Truck Weight, } \\
\mathrm{t}\end{array}$ & 70.00 & 90.00 & 110.00 \\
\hline $\begin{array}{c}\text { Front Axis Tire Load } \\
\text { (Empty), } \mathrm{t}\end{array}$ & 17.500 & 22.500 & 27.500 \\
\hline $\begin{array}{l}\text { Rear Axis Tire Load } \\
\text { (Empty), } \mathrm{t}\end{array}$ & 17.500 & 22.500 & 27.500 \\
\hline $\begin{array}{l}\text { Front Axis Tire Load } \\
\text { (Loaded), } \mathrm{t}\end{array}$ & 40.000 & 50.000 & 60.000 \\
\hline $\begin{array}{l}\text { Rear Axis Tire Load } \\
\text { (Loaded), } \mathrm{t}\end{array}$ & 40.000 & 50.000 & 60.000 \\
\hline
\end{tabular}

To analyze the economic efficiency of the proposed solution for the use of GTs at the CS, we will make calculations depending on the size and number of tires. The calculation results are shown in Table 8.

Table 8. The cost of GT for QDT depending on the size and quantity

\begin{tabular}{|c|c|c|c|c|}
\hline GT Size & $\begin{array}{c}\text { Cost of 4 GTs } \\
\text { from Belshiva }\end{array}$ & $\begin{array}{c}\text { Cost of 4 Im- } \\
\text { ported GTs }\end{array}$ & $\begin{array}{c}\text { Cost of 6 GTs from } \\
\text { Belshiva }\end{array}$ & $\begin{array}{c}\text { Cost of 6 Imported } \\
\text { GTs }\end{array}$ \\
\hline 27.00 R49 & 1800000 RUB & EURO 35 748.98 & 2700000 RUB & EURO 53 623.47 \\
\hline 33.00 R51 & 2800000 RUB & EURO 65 000.00 & 4200000 RUB & EURO 97 500.00 \\
\hline 36.00 R51 & 4800000 RUB & EURO 69 600.00 & 7200000 RUB & EURO 104 400.00 \\
\hline 37.00 R57 & 5569806 RUB & EURO 92 800.00 & 8354709 RUB & EURO 139 200.00 \\
\hline
\end{tabular}

\section{Conclusion}

The analysis of Tabl. 2-5 shows that the GTs from the manufacturer Michelin have a wide range of tires and with different technical characteristics in comparison with other manufacturers, this in turn makes it possible for the technical services of motor transport enterprises to select the GTs for specific conditions operation of QDT.

Thus, the presented calculations (Tab. 6-8) and the proposed configuration of GTs (Fig. 5) allows us to conclude that the proposed scheme can be used when designing new QDT or when upgrading serial GTs. Therefore, the analysis of Tab. 6-8, shows that:

- TKH calculations at the average operating speed of the QDT for a working day $V_{a v}=30$ $\mathrm{km} / \mathrm{h}$ give the opportunity to choose GTs only from the manufacturer Michelin;

- when reducing the operating speed of QDT, then it is possible to choose GTs from other manufacturers;

- the single-tire wheel for the QDT Project 1 (GT size 33.00 R51) has disadvantages in terms of operational productivity and operating costs;

- the single-tire wheel for the QDT Project 2 (GT size 36.00 R51) can be applied to the BelAZ-75131 or Komatsu HD 1500-7 QDT models, and at the same time it can reduce the 
operational costs of transporting minerals to one new purchased set of imported GTs by $28 \%$, and the QDT Project 3 - by $11 \%$.

\section{Acknowledgement}

The research was financially supported by the Ministry of Science and Higher Education of the Russian Federation in the framework of agreement No. 075-11-20 19-034 of November 22, 2019. with PJSC "KAMAZ" on the integrated project "Development and creation of high-tech production of autonomous heavy platforms for unattended mining in the Smart Quarry" system, with the participation of the Federal State Budget Educational Establishment of Higher Education T.F. Gorbachev Kuzbass State Technical University "in terms of the implementation of research, development and technological work.

\section{References}

1. D. M. Dubinkin, Mining Equipment and Electromechanics, 6, 8 (2019)

2. D. V. Stenin, Mining Equipment and Electromechanics. 6, 3 (2019)

3. S. S. Azikhanov, A.R. Bogomolov, G.M. Dubov, S.A. Nokhrin, MATEC Web of Conf., 297, 03001 (2019)

4. G. M. Dubov, D.S. Trukhmanov, S.A. Nokhrin, A.N. Sergel, MATEC Web of Conf., 297, 03002 (2019)

5. D. M. Dubinkin, V.Yu. Sadovets, G.O. Kotiev, A.V. Kartashov, Journal of mining and geotechnical engineering, 4, 7 (2019)

6. Yu. Voronov, An. Voronov, Ar. Voronov, E3S Web Conf., 105, 01048 (2019)

7. V. V. Aksenov, A. B. Efremenkov, V. Yu. Sadovets, D. A. Pashkov, IOP Conference Series: Materials Science and Engineering, 50, 012005 (2018)

8. Yu. Voronov, A. Voronov, S. Grishin, A. Bujankin, E3S Web of Conferences, 21, 02013 (2017)

9. A. N. Egorov, V.T. Voytov, Mining Journal 4-5, 102 (2003)

10. SAE J3016. Taxonomy and Definitions for Terms Related to Driving Automation Systems for On-Road Motor Vehicles (SAE, 2016)

11. S. S. Shadrin, Methodology of autonomous road vehicles, integrated in intellectual transport environment, driving control systems design, (Bauman State Technical University, Moscow, 2017)

12. A. M. Saikin, S. E. Buznikov, K. E. Karpukhi, Research Journal of Pharmaceutical, Biological and Chemical Sciences, 4, 7 (2016)

13. S. S. Shadrin, O. O. Varlamov, A. M. Ivanov, Journal of Advanced Transportation, 1, 10, (2017)

14. Yu. I. Anistratov, K. Yu. Anistratov. Tekhnologicheskie protsessy otkrytykh gornykh rabot. (Gornoe delo, Moscow, 2008)

15. A. Efremenkov, A. Khoreshok, S. Zhironkin, A. Myaskov, IOP Conference Series: Earth and Environmental Science, 50:1, 012009 (2017) 